\title{
ASSESSMENT OF SOIL LOSS FROM LAND USE/LAND COVER CHANGE AND DISASTERS IN THE LONGMEN SHAN MOUNTAINS, CHINA
}

\author{
Chen, P. ${ }^{1}-$ Feng, Z.$^{1 *}$ - MANNAN, A. ${ }^{1}-$ Chen, S. ${ }^{1}-$ Ullah, T. ${ }^{2}$ \\ ${ }^{1}$ Beijing Key Laboratory of Precision Forestry, Beijing Forestry University, Beijing 100083, \\ China \\ ${ }^{2}$ School of Nature Conservation, Beijing Forestry University, Beijing 100083, China \\ *Corresponding author \\ e-mail: fengzhongke@126.com; phone/fax: +86-138-1030-5579
}

(Received $9^{\text {th }}$ Apr 2019; accepted $2^{\text {nd }}$ Jul 2019)

\begin{abstract}
Soil erosion is the main cause of the decline in global available land resources, and China is one of the countries suffering from severe soil erosion. In this paper, the RUSLE model and GIS were used to assess the changes in soil erosion in different ecosystems and counties. The results showed that from 2005 to 2017, the highest rate of ecosystem change was in the other ecosystems category, with an increase in mean soil loss to $4.06 \mathrm{t} \cdot \mathrm{ha}^{-1} \cdot$ year $^{-1}$. For the counties, the highest soil erosion was recorded in Maoxian County during the study period, because Maoxian County was one of the severely affected counties in the Wenchuan Earthquake. The mean soil loss in Yingjing was relatively small, as the estimates for 2005 and 2017 were $0.08 \mathrm{t} \mathrm{ha}^{-1} \cdot \mathrm{year}^{-1}$ and $0.09 \mathrm{t}^{\mathrm{h}} \mathrm{ha}^{-1} \cdot \mathrm{year}^{-1}$, respectively. The areas with severe soil loss are along rivers, mainly distributed along the Minjiang and Tuojiang River basins and their tributaries. The findings of our study will be helpful for identifying high-risk zones, and developing policies to minimize human, environmental and economic losses in any disastrous event.
\end{abstract}

Keywords: soil erosion, revised universal soil loss equation, Landsat, geo-hazards, ecosystem

\section{Introduction}

Soil is a limited natural resource that is vital for human survival (Stefano et al., 2016; Gao and Cao, 2011). Soil erosion is one of the important reasons for the decline in global available land resources. Global soil erosion causes a loss of 2.5 to 4 billion tons of topsoil every year, directly costing $\$ 40$ billion. Soil erosion also leads to a decline in crop yields, hinders global economic development, and poses a threat to food security and human welfare (FAOUN, 2015; Luca, 2015). China has long suffered from soil erosion (Xiao et al., 2016; Gao and Cao, 2011), and approximately 37.6\% of its land resources are affected by soil erosion (Gao et al., 2016; Zhang et al., 2012). Soil erosion is a form of soil degradation, which refers to the process of destruction, separation and sedimentation of soil and its parent material under the external force of hydraulics, wind, freeze-thaw cycles or gravity (Meyer, 1984). Soil erosion has become a focus of global research, because of a series of associated ecological and environmental problems, such as land degradation, and soil fertility loss (Luca, 2015).

The occurrence of soil erosion is determined by natural factors and is influenced by human factors (Guo, 2010). Natural factors determine the occurrence and development of water and soil loss in the region, and human factors have the positive effect of controlling soil loss and have the negative effect of accelerating soil loss, such as land use and land cover (LULC) change (Wischmeier, 1978). Climate change and global warming caused by LULC changes directly or indirectly affect soil erosion at different 
scales, accelerating the soil erosion rate (Konukcu et al., 2017; Nojarov et al., 2015). Other human activities disturb the land surfaces of the earth, thus altering the rate of natural erosion and rate of soil degradation (Rompaey et al., 2010; Sharma et al., 2007). The intensities of soil erosion are closely related to land use and are greatly affected by changes in LULC (Wang et al., 2018; Ferreira et al., 2015; Leh et al., 2013). Many previous studies have shown that changes in land use or surface vegetation accelerate soil erosion (Diyabalanage et al., 2017; Ganasri and Ramesh, 2016; Zhang et al., 2017; Balasubraman et al., 2015).

In addition, the occurrence of earthquakes and secondary geological disasters will also aggravate soil erosion (Hovius et al., 2011; Lin et al., 2006). After an earthquake, the surface soil is easily disturbed or buried by secondary geological disasters, destroying the structure of the surface soil. Secondary geological disasters caused by earthquakes, such as landslides, mudslides, and collapses, provide a large amount of loose solid matter for soil erosion under the influence of external forces such as rainfall, runoff, and earthquakes (Vittoz et al., 2001; Peng et al., 2012). The 5.12 Wenchuan Earthquake (Ms 7.9) was one of the most devastating earthquakes in China. Due to the loose soil, steep slope, surface vegetation destruction and additional rainfall after the earthquake, the soil erosion in this area was intensified. After the earthquake, preliminary statistics from the National Bureau of Statistics of China showed that soil erosion occurred in $149.2 \mathrm{~km}^{2}$ of land, an increase of $11.03 \%$ over the previous period (Gan et al., 2018). The area of vegetation damaged by earthquakes in Sichuan Province is $32.867 \times 10^{4}$ ha (FDSP, 2008). After the vegetation is destroyed, the bedrock is exposed, and the "buffering" protective layer that prevents surface erosion by rainfall is lost, which aggravates the erosion rate of the loose material on the surface layer (Cui et al., 2010). Therefore, it is particularly important to quantify the effects of soil erosion and to develop effective soil protection measures (Santillan et al., 2010).

Numerical models are important methods for assessing and predicting soil erosion (Panagos et al., 2017). Various soil erosion models, including the Universal Soil Loss Equation (USLE) (Wischmeier and Smith, 1978), the Modified USLE (MUSLE) (Williams, 1975), the Revised USLE (RUSLE) (Renard et al., 1997), and the Unit Stream Power-based Erosion Deposition (USPED) (Mitasova et al., 1996), or physically-based models, such as the Water Erosion Prediction Project (WEPP) (Nearing, 1997) and the European Soil Erosion Model (EUROSEM) (Morgan et al., 2015), have been developed for estimating, analysing and predicting soil erosion. Among these models, the RUSLE is the most commonly used to estimate the long-term soil erosion rate of hillsides in large-scale studies (Rulli et al., 2013; Panagos et al., 2015; Ganasri et al., 2016; Zhao et al., 2017). This model has been proven effective for estimating soil loss in different parts of the world. An increasing number of studies combine RUSLE and USLE with 3S (GIS, RS, and global positioning system (GPS)) to detect soil erosion rates at different temporal and spatial scales, along with aerospace and computer technology (Alexakis et al., 2014; Anees et al., 2014).

The study area is in the Longmen Shan fault zone, which is the overlying zone of the Qinghai-Tibet Plateau and the Sichuan Basin. It is an important sensitive zone of China's ecological environment because of its complex geological structures and rich biodiversity. During and after the Wenchuan Earthquake (May 12, 2008) the natural environment of the area in the Longmen Shan fault zone deteriorated. Long-term effects and complex aftershocks have caused a series of environmental problems, such as disturbance of ecosystems, vegetation loss and soil degradation. The objective of this 
study is to use GIS technology to quantitatively evaluate soil erosion in the Longmen Shan area in 2005, 2008, 2010 and 2017 using the RUSLE model to explore the response of soil erosion to LULC changes and the impact of earthquakes on soil erosion. Analysis of the evolution process of soil erosion provides a reference for soil and water conservation in the Longmen Shan area.

\section{Materials and methods}

\section{Study area}

The Longmen Shan fault covering an area of $55213 \mathrm{~km}^{2}$ is extended from Luding and Tianquan in the south to Baoxing, Dujiangyan, Jiangyou and Guangyuan Cities in the northeast, and it enters the area of Ningqiang and Jixian in Shaanxi Province. The total length of the Longmen Shan fault is $500 \mathrm{~km}$, and the width is $40-50 \mathrm{~km}$. The peaks are undulating and the river valleys are both vertical and horizontal. The terrain is extremely complicated and is located in the transition zone between the Tibetan Plateau and Sichuan Basin. The terrain forms a natural boundary between the Chengdu Plain and the western Sichuan Plateau. The area has an elevation range of $309 \sim 7100 \mathrm{~m}$ (Fig. 1), and the overall terrain is high in the west and low in the east, with the highest point being $7100 \mathrm{~m}$ (Yong, 2006). The landform is mainly in the piedmont alluvial plains, mountains and plateaus (Yong, 2006). The Longmen Shan fault zone consists of four nearly parallel faults, namely, the southeastern boundary of the Longmen Shan fault zone, Guanxian-Anxian fault, central main Yingxiu-Beichuan fault, and the northwestern boundary of the Wenchuan-Maoxian and Qingchuan fault. The temperature in the Longmen Shan area decreases with increasing elevation, showing a geographical distribution of high temperatures in the east and low temperatures in the west, and the three-dimensional climate features are obvious, forming a distinct, unique and diversified vertical climate zone in the region. The mountainous areas with an elevation of 1000-2000 m belong to the humid climate zone, while the polar regions with an elevation of 2000-5000 m belong to the cold alpine climate zone ( $\mathrm{Li}, 2013)$. The water system in the Longmen Shan fault area is dominated by horizontal rivers. The river and streams flow perpendicular to the Longmen Mountains and discharge into the Yangtze River. The study area has a rich diversity of plants and animal species, such as Panda, Davidia involucrata, Cercidiphyllum Japonicum, and Ginkgo biloba (Di et al., 2010).

\section{Data acquisition}

The satellite imageries for the years 2005, 2008, 2010 and 2017 were used for this study to see the soil erosion because of LULC changes. Landsat thematic mapping and enhanced thematic mapping (TM and ETM+) for 2005, and SPOT5 and HJ-1 for 2008, 2010, and 2017 were used to classify LULC changes in the study area. TM and $\mathrm{ETM}+$ have a $30 \mathrm{~m}$ spatial resolution. The important possible drivers of LULC change, including the expansion of farmland, massive resettlement and expansion of mechanized farming in recent years, were captured by selecting the specific periods. In addition, field surveys were carried out from July to September identify to various LULC change classes that prevail in the study area. A digital elevation model (DEM) of the study area with a $30 \mathrm{~m}$ resolution was also downloaded from http://www.Gscloud.cn for processing and analysing erosion parameters. 
The rainfall data of Sichuan Province and its surrounding cities were taken from the China Meteorological Science Data Sharing Service Network (http://cdc.Cma.gov.cn), whereas the soil map of the area was obtained from the Nanjing Institute of Soil Science, Chinese Academy of Sciences.

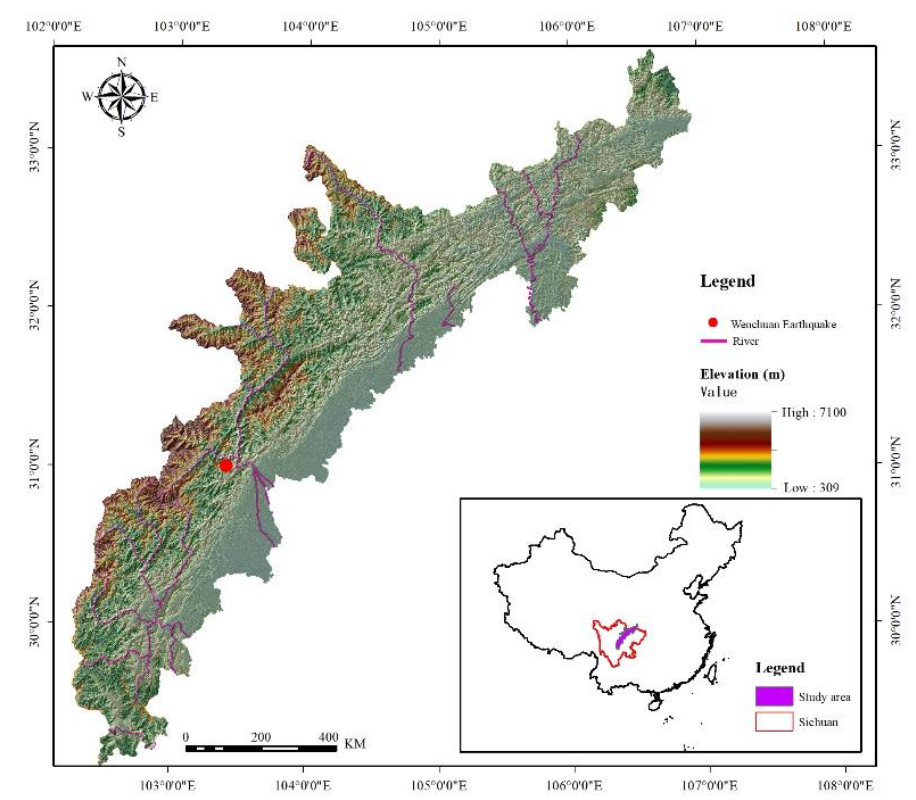

Figure 1. Location and digital elevation model (DEM) of the study area

\section{Methodology}

We used the RUSLE model, which is an improved version of the USLE developed by Wischmeier and Smith (1978), to estimate annual soil loss. The estimate of soil erosion generated by RUSLE, which has been widely used in soil erosion, is reliable (Anees et al., 2018; Haregeweyn et al., 2017). GIS and RUSLE widely adopted conservation-planning tools throughout the world, which are user-friendly and applicable for a basin with limited data. The RUSLE equation is expressed as follows:

$$
\mathrm{A}=R \times K \times L S \times C \times P
$$

where $\mathrm{A}$ is the actual soil loss $\left(\mathrm{t} \mathrm{ha}^{-1} \mathrm{year}^{-1}\right), \mathrm{R}$ is the rainfall erosivity factor (m.t.cm/ha.h.y), $\mathrm{K}$ is the soil erodibility factor (dimensionless), LS is the slope length and slope steepness factor (dimensionless), $\mathrm{C}$ is the cover management factor (dimensionless), and $\mathrm{P}$ is the conservation practices factor (dimensionless).

\section{Estimation of rainfall erosivity ( $R$-factor)}

The rainfall erosivity factor reflects the erosion potential of rainfall under standard conditions. This factor is a dynamic indicator for evaluating soil stripping and handling erosion, and directly affects the prediction accuracy of the soil erosion model (Özşahin et al., 2018). The annual rainfall erosivity value (R) (Wang and Jiao, 1996) was determined by analysing annual rainfall data from 150 stations in Sichuan and its surrounding cities using Equation 2: 


$$
R=0.207\left(P \cdot I_{60} / 100\right)^{1.205}
$$

where $\mathrm{R}$ is the annual erosivity (m.t.cm/ha.h.y), $\mathrm{I}_{60}$-year is the maximum $60 \mathrm{~min}$ rainfall $(\mathrm{mm})$, and P-year is the rainfall total $(\mathrm{mm})$. In this study, the $\mathrm{R}$ value of the rainfall station in the Longmen Shan area and surrounding provinces was calculated by the above formula (Eq. 2), and then, the R-value map of the Longmen Shan area was obtained by interpolation using "Kriging" in the ArcGIS platform (Diodato and Bellocchi, 2007).

\section{Soil erodibility factor estimation ( $K$-factor)}

The soil erodibility factor $(\mathrm{K})$ is a quantitative description of the intrinsic erodibility of a particular soil and an indicator of the sensitivity of soil properties to erosion (Zhai et al., 2011). The K-factor represents the relationship among annual average soil loss, hydraulic processes, and sediment transportability under ordinary soil conditions (Özşahin et al., 2018). In this study, the K-factor was estimated by combining the results of the studies (Zhujun et al., 2019; Wang et al., 2018) utilizing Equation 3:

$$
\begin{aligned}
& K=\left\{0.2+0.3 \exp \left[-0.0256 * S A N\left(1-\frac{S I L}{100}\right)\right]\right\}\left(\frac{S I L}{C L A+S I L}\right)^{0.3} * \\
& \left(1.0-\frac{0.25 C}{C+\exp (3.72-2.95 C)}\right) *\left(1.0-\frac{0.25 S N 1}{S N 1+\exp (-5.51+22.9 S N 1)}\right)
\end{aligned}
$$

$$
S N 1=1-S A N / 100
$$

where SAN, SIL, and CLA are the mass fractions (\%) of sand, silt and clay, respectively; and $\mathrm{C}$ is the mass fraction of soil organic carbon (SOC) (\%). The soil type and the SOC data were captured from the soil data.

The K-factor map, obtained using the kriging spatial interpolation method in GIS, is more suitable for soil moisture spatial interpolation in the Longmen Shan region (Yao et al., 2013).

\section{Estimation of the slope length and slope gradient factor (LS-factor)}

The LS-factor in RUSLE reflects the ratio of gross soil loss under given conditions with respect to slope length (L-factor) and slope steepness (S-factor) (Renard et al., 1997). The slope length is closely related to soil erosion. On a regional scale, the factors, including the slope length (L) and slope steepness (S), were calculated by using the DEM $(30 \mathrm{~m} \times 30 \mathrm{~m})$ of the study area. The method developed by Wischmeier and Smith was adopted to calculate L using Equation 5:

$$
\left\{\begin{array}{l}
L=(\lambda / 22.13)^{\alpha} \\
\alpha=\beta(\beta+1) \\
\beta=(\sin \theta / 0.089) /\left[3.0 \times(\sin \theta)^{0.8}+0.56\right]
\end{array}\right.
$$

where $\lambda$ is the slope length $(\mathrm{m}), 22.13$ represents the slope length of the standard district (m), $\alpha$ is the index of the slope length calculated using the method by Renard (1997), $\beta$ 
indicates the ratio of rill to inter rill erosion, and $\theta$ represents the slope gradient extracted from the DEM data. The effect of slope gradient on erosion (Zhao et al., 2017) is represented by the steepness factor (S) of the slope, which is calculated using the equation established by Liu et al. (Liu et al., 2000). The greater the slope steepness factor is, the greater the possibility of soil loss and the more severe the soil erosion. The slope steepness factor is calculated as follows:

$$
\begin{cases}S=10.8 \times \sin \theta+0.03 & \theta<5^{\circ} \\ S=16.8 \times \sin \theta-0.5 & 5^{\circ} \leq \theta<10^{\circ} \\ S=21.91 \times \sin \theta-0.96 & \theta \geq 10^{\circ}\end{cases}
$$

Based on the Map algebra function in ArcGIS (Version 10.2), L was calculated according to the equation. The LS value distribution is calculated by multiplying the spatial distribution of the $\mathrm{S}$ and $\mathrm{L}$ factors.

\section{Estimation of cover management factor and support practice factor ( $C$ and $P$ factor)}

The $\mathrm{C}$ value reflects the impact of crop and management activities on erosion rate. The protective vegetation layer helps stabilize topsoil, thus preventing soil degradation, and plays an important role in enhancing soil impact resistance. The $\mathrm{C}$ value is an important indicator to evaluate the influence of vegetation factors on soil erosion capacity (Rao et al., 2013). The $\mathrm{P}$ value is the ratio of the amount of soil loss after soil conservation measures to the amount of soil loss without any soil conservation measures. This value reflects the inhibition of soil erosion by soil conservation measures. The $\mathrm{C}$ and $\mathrm{P}$ factors are dimensionless numbers between 0 and 1 . In this study, by referring to the literature data, the $\mathrm{C}$ and the $\mathrm{P}$ values corresponding to the land use type are selected (Table 1), and the model automatically converts the field into a raster layer (Ran, 2015; Teng et al., 2018).

\section{Results and discussion}

The results revealed that significant LULC occurred in the Longmen Shan region (Fig. 2) after the Wenchuan Earthquake. The dynamic parameters (rainfall erosivity, cover management and conservation practices) were measured for 2005, 2008, 2010 and 2017. The different input parameters have the capacity to alter the rate of soil erosion (Özşahin et al., 2018). The precipitation data for 2005, 2008 and 2010 were merely used for R-factor values, and the results were 421.86 m.t.cm/ha.h.y, 392.04 m.t.cm/ha.h.y, 451.69 m.t.cm/ha.h.y and 402.37 m.t.cm/ha.h.y, respectively. The R-factor values in 2008 were lower than those in the other years. Vegetation cover is an important component of any prediction model, because it is the erosion risk variable most affected by human manipulation (Sahin and Kurum, 2002). In contrast, the C-factor values spatiotemporally varied due to LULC in the study area, such as the increase in the settlement and bare areas by $317 \mathrm{~km}^{2}$ and $138 \mathrm{~km}^{2}$, respectively, from 2005 to 2017. However, the LS and $\mathrm{K}$ factors are presented as individual maps because they do not change over time. The K-factor and a higher magnitude of the LS-factor were obtained in the Longmen Shan area. 
Table 1. Cover management factor $(C)$ and support practice factor $(P)$ values according to LULC classes

\begin{tabular}{c|c|c|c}
\hline Ecosystem type & Land use type & C value & P value \\
\hline \multirow{5}{*}{ Forest ecosystem } & Evergreen Needleleaf Forest & 0.12 & 1 \\
& Evergreen Broadleaf Forest & 0.12 & 1 \\
& Deciduous Needleleaf Forest & 0.12 & 1 \\
& Deciduous Broadleaf Forest & 0.12 & 1 \\
& Mixed Forests & 0.12 & 1 \\
& Shrub Forest & 0.12 & 1 \\
\hline \multirow{5}{*}{ Grassland ecosystem } & Meadow & 0.18 & 1 \\
& Barren Grassland & 0.18 & 1 \\
& Alpine Meadow & 0.18 & 1 \\
Farmland ecosystem & Shrub Grassland & 0.18 & 1 \\
\hline \multirow{3}{*}{ Settlement } & Paddy Field & 0.25 & 0.15 \\
& Irrigated Cropland & 0.22 & 0.6 \\
& Dryland Cropland & 0.22 & 0.6 \\
\hline \multirow{3}{*}{ Wetland ecosystem } & Urban and Built-up & 0 & 0 \\
& Rural Settlement & 0 & 0 \\
\hline \multirow{3}{*}{ Others } & Swamp & 0.05 & 1 \\
& Seaside Wetlands & 0 & 0 \\
& Water Bodies & 0 & 0 \\
& Bottom Land & 0 & 0 \\
& Ice and Snow & 0 & 0 \\
\hline \multirow{5}{*}{} & Bare Rock & 0 & 0 \\
& Bare Land & 1 & 1 \\
\hline
\end{tabular}

\section{LULC change}

The rate of LULC change was computed from 2005 to 2017 (Table 2). The forest ecosystem area decreased by $-181 \mathrm{~km}^{2}$, and the rate of change in the forest ecosystem is relatively stable. The grassland and farmland ecosystem areas decreased by $-336 \mathrm{~km}^{2}$ and $-334 \mathrm{~km}^{2}$, respectively, from 2005 to 2017 . The grassland ecosystem and farmland ecosystem have shown a negative rate of change for the study periods. The farmland ecosystem showed the highest rate of changes $(-0.16 \%)$ in the period (2005-2017). In contrast, settlement, wetland ecosystems and other ecosystems showed a positive rate of change for both periods. Settlements and other ecosystems showed the highest rate of change (2.32\% and $4 \%$, respectively) in the period, and the areas of the settlement ecosystem and other ecosystems increased by $317 \mathrm{~km}^{2}$ and $138 \mathrm{~km}^{2}$, respectively.

Rapid and massive population growth, the main factor of these LULC changes, leads to overexploitation of natural resources and destruction of the ecological environment caused by the devastating May 12, 2008 Wenchuan Earthquake (Peng et al., 2012). In general, slope steepness, geology and shaking intensity are the main factors that affect the distribution of earthquake-induced landslides (Wang et al., 2007). Furthermore, Di et al. (2010) observed that the combination of elevation and slope may have contributed most to the distribution of mass landslides triggered by the Wenchuan Earthquake. 

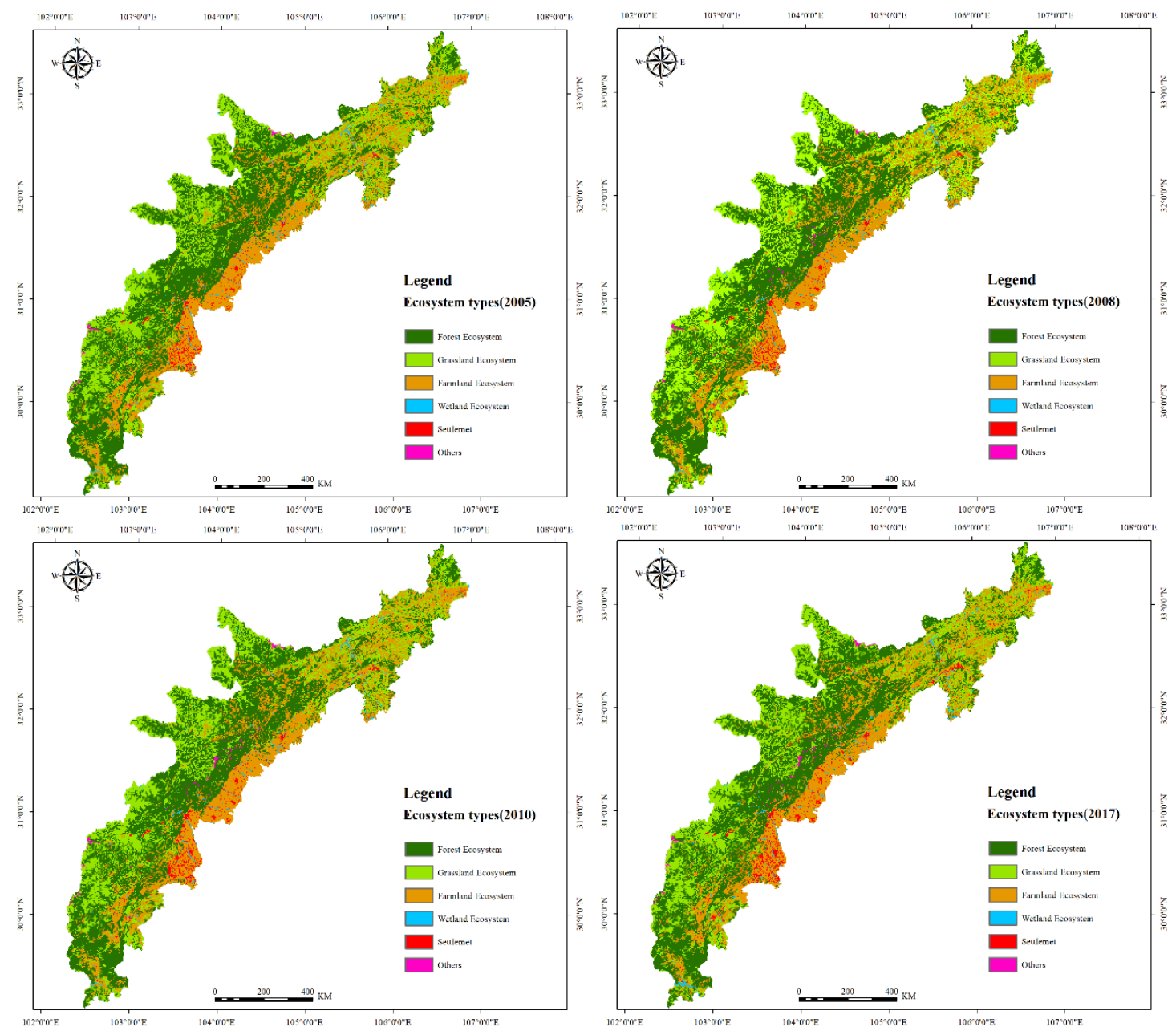

Figure 2. Ecosystem types of 2005, 2008, 2010 and 2017 in the study area

Table 2. Change in land use and land cover

\begin{tabular}{c|c|c|c|c|c|c|c|c|c|c}
\hline \multirow{2}{*}{ Ecosystem } & \multicolumn{2}{|c|}{2005} & \multicolumn{2}{c|}{2008} & \multicolumn{2}{c|}{$\mathbf{2 0 1 0}$} & \multicolumn{2}{c|}{$\mathbf{2 0 1 7}$} & \multicolumn{2}{c}{$\begin{array}{c}\mathbf{2 0 0 5 - 2 0 1 7} \\
\text { Change }\end{array}$} \\
\cline { 2 - 11 } & $\begin{array}{c}\text { Area } \\
\left(\mathbf{k m}^{2}\right)\end{array}$ & $\begin{array}{c}\text { Rate } \\
(\%)\end{array}$ & $\begin{array}{c}\text { Area } \\
\left(\mathbf{k m}^{2}\right)\end{array}$ & $\begin{array}{c}\text { Rate } \\
(\%)\end{array}$ & $\begin{array}{c}\text { Area } \\
\left(\mathbf{k m}^{2}\right)\end{array}$ & $\begin{array}{c}\text { Rate } \\
(\%)\end{array}$ & $\begin{array}{c}\text { Area } \\
\left(\mathbf{k m}^{2}\right)\end{array}$ & $\begin{array}{c}\text { Rate } \\
(\boldsymbol{\%})\end{array}$ & $\begin{array}{c}\text { Area } \\
\left(\mathbf{k m}^{2}\right)\end{array}$ & $\begin{array}{c}\text { Rate } \\
(\%)\end{array}$ \\
\hline Forest & 23929 & 41.82 & 24045 & 42.02 & 23979 & 41.90 & 23748 & 41.73 & -181 & -0.05 \\
Grassland & 15996 & 27.96 & 15837 & 27.68 & 15853 & 27.70 & 15660 & 27.52 & -336 & -0.14 \\
Farmland & 14009 & 24.48 & 13923 & 24.33 & 13816 & 24.14 & 13675 & 24.03 & -334 & -0.16 \\
Settlement & 780 & 1.36 & 805 & 1.41 & 911 & 1.59 & 1097 & 1.93 & 317 & 2.32 \\
Wetland & 390 & 0.68 & 424 & 0.74 & 424 & 0.74 & 467 & 0.82 & 77 & 1.21 \\
Other & 109 & 0.19 & 179 & 0.31 & 230 & 0.40 & 247 & 0.43 & 138 & 4.00 \\
\hline
\end{tabular}

\section{Soil loss of different ecological types}

The soil loss was estimated by integrating the maps of the six RUSLE factors in a GIS environment. An overall increase in soil loss was observed for forest ecosystems, 
grassland ecosystems, farmland ecosystems and other ecosystems from 2005 to 2010 (Table 3), and from 2010 to 2017, the soil loss for forest ecosystems, grassland ecosystems, farmland ecosystems and other ecosystems decreased. The total soil loss of the forest ecosystem in 2005, 2008, 2010 and 2017 was $276.88 \times 10^{4} \mathrm{t} \mathrm{ha}^{-1}$.year ${ }^{-1}$, $258.26 \times 10^{4} \mathrm{t} \mathrm{ha}^{-1} \cdot$ year $^{-1}, 295.76 \times 10^{4} \mathrm{t} \mathrm{ha}^{-1}$ year $^{-1}, 152.62 \times 10^{4} \mathrm{t} \mathrm{ha}^{-1} \cdot$ year $^{-1}$, respectively. The total soil loss of theg rassland ecosystem in 2005, 2008, 2010 and 2017 was $192.77 \times 10^{4} \mathrm{t} \mathrm{ha}^{-1} \cdot$ year $^{-1}, 176.48 \times 10^{4} \mathrm{tha}^{-1} \cdot$ year $^{-1}, 204.43 \times 10^{4} \mathrm{t} \mathrm{ha}^{-1} \cdot$ year $^{-1}$, $156.34 \times 10^{4} \mathrm{t} \mathrm{ha}^{-1} \cdot$ year $^{-1}$, respectively. The total soil loss of the farmland ecosystem in 2005, 2008, 2010 and 2017 was $129.21 \times 10^{4} \mathrm{t} \mathrm{ha}^{-1} \cdot$ year $^{-1}, 118.00 \times 10^{4} \mathrm{t} \mathrm{ha}^{-1} \cdot$ year $^{-1}$, $135.34 \times 10^{4} \mathrm{t} \mathrm{ha}^{-1} \cdot$ year $^{-1}$, and $111.52 \times 10^{4} \mathrm{tha}^{-1} \cdot$ year $^{-1}$, respectively. The total soil loss of the other ecosystems in 2008, 2010 and 2017 was $3.36 \times 10^{4} \mathrm{t} \mathrm{ha}^{-1} \cdot$ year $^{-1}, 4.02 \times 10^{4}$ $\mathrm{t} \cdot \mathrm{ha}^{-1} \cdot$ year $^{-1}$, and $10.03 \times 10^{4} \mathrm{t} \mathrm{ha}^{-1} \cdot$ year $^{-1}$, respectively. The amount of soil loss in 2017 was lowest. From 2005 to 2017, the contribution to total soil loss of the forest ecosystem decreased by $35.45 \%$, and that of the grassland ecosystem and farmland ecosystem increased by $36.32 \%$ and $25.9 \%$, respectively. The total soil loss of the other ecosystems increased by $2.33 \%$, and in 2008 , it increased by $0.60 \%$ because of the Wenchuan Earthquake. Geo-hazards induced by the Wenchuan Earthquake resulted in intense surface material movement that led to the removal and destruction of a large area of vegetation. In the upper Minjiang River, forest cover decreased from $28.44 \%$ in 2005 to $24.45 \%$ in 2008 after the earthquake (Cui et al., 2009; Huang et al., 2009). In Xuanping and Yuli towns, $17.79 \times 10^{4} \mathrm{~m}^{2}$ and $1.549 \mathrm{~km}^{2}$, respectively, of farmlands and forests were submerged along the rising water level of rivers and valleys (Fan et al., 2008).

Table 3. Soil loss of different ecological types

\begin{tabular}{|c|c|c|c|c|c|c|c|c|c|c|c|c|}
\hline \multirow[t]{2}{*}{ Soil loss } & \multicolumn{4}{|c|}{$\begin{array}{c}\text { Total soil loss }\left(\times 10^{4}\right) \\
\left(t \cdot \text { year }^{-1}\right)\end{array}$} & \multicolumn{4}{|c|}{$\begin{array}{c}\text { Mean soil loss } \\
\left(\mathbf{t} \cdot \mathbf{h a}^{-1} \cdot \text { year }^{-1}\right)\end{array}$} & \multicolumn{4}{|c|}{$\begin{array}{c}\text { \% Contribution to total soil } \\
\text { loss }\end{array}$} \\
\hline & 2005 & 2008 & 2010 & 2017 & 2005 & 2008 & 2010 & 2017 & 2005 & 2008 & 2010 & 2017 \\
\hline Forest & 276.88 & 258.26 & 295.76 & 152.62 & 1.16 & 1.07 & 1.23 & 0.64 & 46.23 & 46.44 & 46.24 & 35.45 \\
\hline Grassland & 192.77 & 176.48 & 204.43 & 156.34 & 1.21 & 1.11 & 1.29 & 1 & 32.19 & 31.74 & 31.97 & 36.32 \\
\hline Farmland & 129.21 & 118 & 135.34 & 111.52 & 0.92 & 0.85 & 0.98 & 0.82 & 21.58 & 21.22 & 21.16 & 25.90 \\
\hline Settlement & 0 & 0 & 0 & 0 & 0 & 0 & 0 & 0 & 0 & 0 & 0 & 0 \\
\hline Wetland & 0 & 0 & 0 & 0 & 0 & 0 & 0 & 0 & 0 & 0 & 0 & 0 \\
\hline Other & 0 & 3.36 & 4.02 & 10.03 & 0 & 1.88 & 1.75 & 4.06 & 0 & 0.6 & 0.63 & 2.33 \\
\hline
\end{tabular}

\section{Soil loss at the district and county scales}

The areas with the highest soil erosion in the Longmen Shan area are mainly distributed in the western part of the Longmen Shan fault zone over a long, narrow area, and are mainly located in Qingchuan, northwest Pingwu, Maoxian, Wenchuan, Baoxing and Hanyuan Counties (Fig. 3; Table 4). Soil erosion in Maoxian County was the most devastating, with a mean soil loss value in 2005, 2008, 2010 and 2017 of $2.3 \mathrm{t} \mathrm{ha}^{-1}$.year 1, $2.13 \mathrm{t} \mathrm{ha}^{-1} \cdot$ year $^{-1}, 2.45 \mathrm{t} \mathrm{ha}^{-1} \cdot$ year $^{-1}$, and $1.55 \mathrm{t} \cdot \mathrm{ha}^{-1} \cdot$ year $^{-1}$, respectively, which contributed to total soil losses of $14.77 \%, 14.74 \%, 14.76 \%$, and $13.87 \%$, respectively. Wenchuan, Baoxing and Hanyuan Counties account for more than $10 \%$ of the total area. 

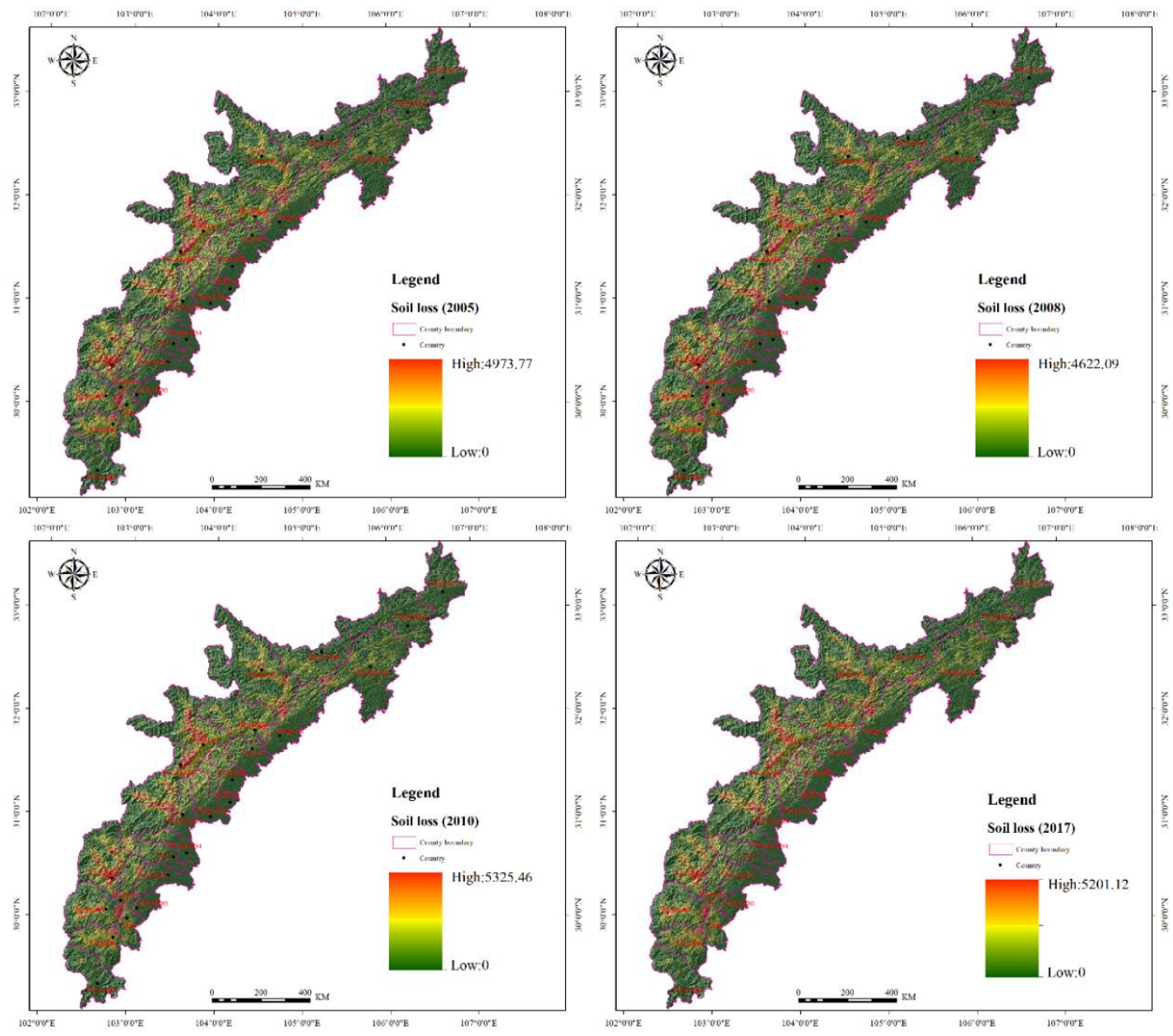

Figure 3. Soil loss on county scale in 2005, 2008, 2010 and 2017 in the study area

Less soil erosion was reported at lower elevations. These areas are mainly distributed in the eastern part of the Longmen Shan fault zone: Guanyuan, Jianyou, Anxian, Shifang, Mianzhu, Pengzhou, Dujiangyan, Chongzhou, Dayi, Handan, Mingshan, Yaan, etc. The soil loss of Yingjing was relatively small, with mean soil loss values in 2005, 2008, 2010 and 2017 of $0.08 \mathrm{t} \mathrm{ha}^{-1} \cdot$ year $^{-1}, 0.08 \mathrm{t} \mathrm{ha}^{-1} \cdot$ year $^{-1}, 0.09 \mathrm{t} \cdot \mathrm{ha}^{-1} \cdot$ year $^{-1}, 0.09 \mathrm{t} \cdot \mathrm{ha}^{-}$ ${ }^{1}$. year $^{-1}$, respectively, which contributed to total soil losses of $0.32 \%, 0.33 \%, 0.33 \%$, and $0.52 \%$, respectively.

The areas with severe soil loss are mainly distributed along the Minjiang River and its tributaries at higher elevations in the western Longmen. The 2008 Wenchuan Earthquake caused severe damage to the vegetation in the area, increased surface exposure, and caused frequent occurrences of geological disasters such as mudslides and landslides after the earthquake, resulting in an increase in soil loss in 2010. A geological survey in Sichuan Province recorded 3286 landslides and 1218 rock avalanches in the different counties after the earthquake (Li et al., 2011). A massive magnitude of denudation occurs frequently in 3 to 5 years after a strong earthquake e.g., the large debris flow disaster in 2010 after the 2008 Wenchuan Earthquake (Tang et al., 2011). Vegetation along rivers and valleys has been destroyed by debris flows, which also limit potential vegetation restoration (Cui et al., 2009). In the seven years after the 
Wenchuan Earthquake, there were six large-scale debris flow disasters in the BaishaLongxi River basin, covering an area of $188.5 \mathrm{~km}^{2}$ (Peng et al., 2012).

Table 4. The list of soil loss according to different ecological types

\begin{tabular}{|c|c|c|c|c|c|c|c|c|c|c|c|c|}
\hline \multirow[t]{2}{*}{ Soil loss } & \multicolumn{4}{|c|}{$\begin{array}{c}\text { Total soil loss }\left(\times 10^{4}\right) \\
\left(t \cdot \text { year }^{-1}\right)\end{array}$} & \multicolumn{4}{|c|}{$\begin{array}{l}\text { Mean soil loss } \\
\left(\mathbf{t} \cdot \mathbf{h a}^{-1} \cdot \text { year }^{-1}\right)\end{array}$} & \multicolumn{4}{|c|}{$\begin{array}{c}\% \text { Contribution to total soil } \\
\text { loss }\end{array}$} \\
\hline & 2005 & 2008 & 2010 & 2017 & 2005 & 2008 & 2010 & 2017 & 2005 & 2008 & 2010 & 2017 \\
\hline Jiangyou & 20.05 & 3.54 & 21.36 & 4.04 & .74 & 68 & 79 & 0.52 & .35 & 3.33 & 3.34 & 3.26 \\
\hline Maoxian & 88.48 & 81.96 & 94.37 & .70 & 2.30 & 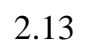 & & 1.55 & 14.77 & 14.74 & 14.76 & 13.87 \\
\hline Beichuan & 39.26 & 36.47 & 41.62 & 28.72 & 1.35 & 1.25 & 1.43 & 0.99 & 6.56 & 6.56 & 6.51 & 6.67 \\
\hline Wenchuan & 83.59 & 76.79 & 88.63 & 9.48 & 2.04 & & & & 13.96 & 13.81 & 13.86 & 11.49 \\
\hline Mianzhu & 9.48 & 9. & 10.75 & & 0.75 & 0.76 & & 0.64 & 1.58 & 1.71 & 1.68 & 1.87 \\
\hline Shifang & 7.29 & 6.97 & 7.85 & 5.16 & 0.85 & 0.81 & 0.91 & 0.60 & 1.22 & 1.25 & 1.23 & 1.20 \\
\hline Pengzhou & 11.99 & 11.55 & 13.05 & 8.21 & 0.84 & 0.81 & & 0.57 & 2. & 2.08 & 2.04 & 1.91 \\
\hline Dujiangyan & 12.85 & 11.22 & 12.93 & 8.13 & 1.07 & 0.93 & 08 & 0.68 & 2.15 & 2.02 & 2.02 & 1.89 \\
\hline Baoxing & 82.98 & 76.95 & 88.66 & 55.23 & 2.66 & & & 1.77 & 13.86 & 13.84 & 13.86 & 12.83 \\
\hline Chongzhou & 3.57 & 3.32 & 3.81 & 1.93 & 0.32 & 0.30 & 0.35 & 0.18 & 0.60 & 0.60 & 0.60 & 0.45 \\
\hline Dayi & 5.38 & & & & 0.45 & & & 0.2 & & 0.90 & 0.90 & 0.70 \\
\hline Lushan & 25.30 & 23.51 & 27.08 & 16.66 & 2.01 & 1.87 & 2.15 & 1.33 & 4.22 & 4.23 & 4.23 & 3.87 \\
\hline Qionglai & 4.09 & & & & 0.30 & 0.2 & & 0.17 & 0.68 & 0.68 & 0.69 & 0.54 \\
\hline Anxian & 36.65 & 34.01 & 39.18 & 28.71 & 1.52 & & & 1.19 & 6. & 6.12 & 6.13 & 6.67 \\
\hline Pingwu & 0.46 & & 0.49 & 0.35 & 0.07 & 0.07 & & 0.06 & 0. & 0.08 & 0.08 & 0.08 \\
\hline Qingchuan & 11.11 & 10.7 & 11.85 & & 1.06 & & & & & 1.86 & 1.85 & 1.93 \\
\hline Tianquan & 25.41 & 23.61 & 27.16 & 18.92 & 1.44 & 1.34 & 1.54 & 1.07 & 4.24 & 4.25 & 4.25 & 4.39 \\
\hline Mingshan & 5.95 & 6.19 & 7.09 & 4.66 & 0.43 & 0.45 & 0.51 & 0.34 & 0.99 & 1.11 & 1.11 & 1.08 \\
\hline Yaan & 3.28 & 3.0 & 3.51 & 2.99 & 0.15 & 0.14 & & 0.14 & 0.55 & 0.55 & 0.55 & 0.69 \\
\hline Yingjing & 1.95 & 1.81 & 2.08 & 2.24 & 0.08 & 0.08 & 0.09 & 0.09 & 0.32 & 0.33 & 0.33 & 0.52 \\
\hline & 66.00 & 61.30 & 70.62 & 54.22 & 1.12 & & & 0.92 & 11.02 & 11.02 & 11.04 & 12.60 \\
\hline Mianxian & 6.90 & 6.41 & 7.39 & 7.39 & 0.21 & 0.20 & 0.23 & 0.23 & 1.15 & 1.15 & 1.16 & 1.72 \\
\hline Ningqiang & 17.12 & 15.85 & 18.24 & 15.80 & 0.58 & 0.54 & 0.62 & 0.54 & 2.86 & 2.85 & 2.85 & 3.67 \\
\hline Guanyuan & 29.73 & 27.50 & 31.66 & 26.31 & 0.60 & 0.55 & 0.64 & 0.53 & 4.96 & 4.95 & 4.95 & 6.11 \\
\hline
\end{tabular}

\section{Conclusion}

In this study, LULC changes were monitored in Longmen Shan in 2005, 2008, 2010 and 2017 using remote sensing and GIS approach. The map of LULC changes illustrates positive growth in the settlement ecosystem and other ecosystems, which led to a sharp increase in industrialization and geo-hazards induced by the Wenchuan Earthquake. Negative growth has also been observed in the grassland ecosystem and farmland ecosystem due to destruction of the ecological environment. The areas with severe soil loss are mainly distributed along rivers in the high-elevation areas of the western Longmen Mountains and along the Minjiang and Tuojiang River basins and their tributaries.

Risk monitoring of heterogeneous regions in different time series can provide a timely understanding of the status of soil erosion and make reliable predictions. In future research, the erosion model can also be used to predict climate change scenarios, and thus be used for effective erosion management practices. Therefore, the results of 
this study can adequately show the distribution of soil erosion in the region, and provide an important reference for decision makers to develop appropriate solutions. Finally, the ideas, modelling methods and corresponding policies used in this study are helpful for providing important references for soil erosion analysis in other regions.

Acknowledgements. The research reported in this manuscript is funded by the Fundamental Research Funds for the Central Universities (Grant No. 2015ZCQ-LX-01), the National Natural Science Foundation of China (Grant No. U1710123).

\section{REFERENCES}

[1] Alexakis, D. D., Gryllakis, M. G., Koutroulis, A. G., Agapiou, A., Themistocleous, K., Tsanis, I. K., Michaelides, S., Pashiardis, S., Demetriou, C., Aristeidou, K. (2013): GIS and remote sensing techniques for the assessment of land use change impact on flood hydrology: The case study of Yialias basin in Cyprus. - Natural Hazards Earth System Sciences Discussions 1: 4833-4869.

[2] Anees, M. T., Abdullah, K., Nawawi, M. N. M., Norulaini, N. A. N., Syakir, M. I., Omar, A. K. M. (2018): Soil erosion analysis by RUSLE and sediment yield models using remote sensing and GIS in Kelantan state, Peninsular Malaysia. - Soil Research 56(4).

[3] Anees, M. T., Javed, A., Khanday, M. Y. (2014): Spatio-temporal land cover analysis in Makhawan watershed (M.P.), India through remote sensing and GIS techniques. Journal of Geographic Information System 6: 298-306.

[4] Balasubramani, K., Veena, M., Kumaraswamy, K., Saravanabavan, V. (2015): Estimation of soil erosion in a semi-arid watershed of Tamil Nadu (India) using revised universal soil loss equation (RUSLE) model through GIS. - Modeling Earth Systems Environment 1: 117.

[5] Cui, P., Zhu, Y. Y., Han, Y. S., Chen, X. Q., Zhuang, J. Q. (2009): The 12 May Wenchuan earthquake-induced landslide lakes: distribution and preliminary risk evaluation. - Landslides 6: 209-223.

[6] Cui, P., Zhuang, J. Q., Chen, X. C., Zhang, J. Q., Zhou, X. J. (2010): Characteristics and countermeasures of debris flow in Wenchuan area after the earthquake. - Journal of Sichuan University 42: 10-19.

[7] Di, B., Zeng, H., Zhang, M., Ustin, S. L., Tang, Y., Wang, Z., Chen, N., Zhang, B. (2010): Quantifying the spatial distribution of soil mass wasting processes after the 2008 earthquake in Wenchuan, China: a case study of the Longmenshan area. - Remote Sensing of Environment 114: 761-771.

[8] Diodato, N., Bellocchi, G. (2007): Estimating monthly (R)USLE climate input in a Mediterranean region using limited data. - Journal of Hydrology 345: 224-236.

[9] Diyabalanage, S., Samarakoon, K. K., Adikari, S. B., Hewawasam, T. (2017): Impact of soil and water conservation measures on soil erosion rate and sediment yields in a tropical watershed in the Central Highlands of Sri Lanka. - Applied Geography 79: 103-114.

[10] Fan, J., Tian, B., Cheng, G., Tao, H., Zhang, J., Yan, D., Fenghuan, S. U., Liu, B. (2008): Investigation on damming object induced by the earthquake of Wenchuan on May 12 based on multi-platform remote sensing. - Journal of Mountain Science 26: 257-262.

[11] Ferreira, V., Panagopoulos, T., Cakula, A., Andrade, R., Arvela, A. (2015): Predicting soil erosion after land use changes for irrigating agriculture in a large reservoir of southern Portugal. - Agriculture, Agricultural Science Procedia 4: 40-49.

[12] Food and Agriculture Organization of the United Nations (FAOUN) (2015): Status of the World's Soil Resources. - FAOUN, Washington, DC.

[13] Forestry Department of Sichuan Province (FDSP) (2008): The Report of Thematic Evaluation on Forest Loss in Wenchuan Earthquake. - FDSP, China. 
[14] Gan, F., He, B., Wang, T. (2018): Water and soil loss from landslide deposits as a function of gravel content in the Wenchuan earthquake area, China, revealed by artificial rainfall simulations. - Plos One 13: e0196657.

[15] Ganasri, B. P., Ramesh, H. (2016): Assessment of soil erosion by RUSLE model using remote sensing and GIS. A case study of Nethravathi Basin. - Geoscience Frontiers 7: 953-961.

[16] Gao, H., Zhanbin, L. I., Jia, L., Li, P., Guoce, X. U., Ren, Z., Pang, G. (2016): Capacity of soil loss control in the Loess Plateau based on soil erosion control degree. - Journal of Geographical Sciences 26: 457-472.

[17] Gao, Y., Cao, S. (2011): A degradation threshold for irreversible loss of soil productivity: a long-term case study in China. - Journal of Applied Ecology 48: 1145-1154.

[18] Guo, S, Y. (2010): Theory and Method of Soil and Water Conservation Monitoring. China Water Conservancy and Hydropower Press, Beijing, China.

[19] Haregeweyn, N., Tsunekawa, A., Poesen, J., Tsubo, M., Meshesha, D. T., Fenta, A. A., Nyssen, J., Adgo, E. (2017): Comprehensive assessment of soil erosion risk for better land use planning in river basins: case study of the Upper Blue Nile River. - Science of the Total Environment 574: 95-108.

[20] Hovius, N., Meunier, P., Lin, C. W., Chen, H., Chen, Y. G., Dadson, S., Horng, M. J., Lines, M. (2011): Prolonged seismically induced erosion and the mass balance of a large earthquake. - Earth Planetary Science Letters 304: 347-355.

[21] Huang, G. Z., Liu, X. D., He, F. 2009. Damaged vegetation conditions and reconstruction countermeasures for calamity regions in the upper reach of Minjiang River. -Journal of Sichuan Forestry Science and Technology 30 (3):95-99.

[22] Konukcu, F., Albut, S., Altürk, B. (2017): Land use/land cover change modelling of Ergene River basin in Western Turkey using CORINE land use/land cover data. Agronomy Research 15(2): 435-443.

[23] Leh, M., Bajwa, S., Chaubey, I. (2013): Impact of land use change on erosion risk: an integrated remote sensing, geographic information system and modeling methodology. Land Degradation Development 24: 409-421.

[24] Lin, W. T., Lin, C. Y., Chou, W. C. (2006): Assessment of vegetation recovery and soil erosion at landslides caused by a catastrophic earthquake: a case study in Central Taiwan. - Ecological Engineering 28: 79-89.

[25] Li, Y, J. (2013): Research on Geological Landscape and Suitability of Traditional Settlements in Middle North Section of Long-men Mountain. - Chengdu University of Technology, Chengdu, pp. 24-50.

[26] Li, Q. A. N., Zhang, J. F., Zhao, F. J. (2011): Extracting secondary disaster of Wenchuan earthquake: application of object-oriented image-classifying technology. - Journal of Natural Disasters 20: 160-168.

[27] Liu, B. Y., Nearing, M. A., Shi, P. J., Jia, Z. W. (2000): Slope length effects on soil loss for steep slopes. - Soil Science Society of America Journal 64: 1759-1763.

[28] Luca, M. (2015): Govern our soils. - Nature 528(7580): 32-33.

[29] Morgan, R. P. C., Quinton, J. N., Smith, R. E., Govers, G., Poesen, J. W. A., Auerswald, K., Chisci, G., Torri, D., Styczen, M. E. (2015): The EUROpean Soil Erosion Model (EUROSEM): a dynamic approach for predicting sediment transport from fields and small catchment. - Earth Surface Processes Landforms 23: 527-544.

[30] Meyer, L, D. (1984): Evaluation of the universal soil loss equation. - Soil Water Conservation 39: 99-104.

[31] Mitasova, H., Hofierka, J., Zlocha, M., Iverson, L. R. (1996): Modelling topographic potential for erosion and deposition using GIS. - International Journal of Geographical Information Systems 10: 629-641.

[32] Nearing, M. A. (1997): A single, continuous function for slope steepness influence on soil loss. - Soil Science Society of America Journal 61: 917-919. 
[33] Nojarov, P. (2015): Circulation factors affecting precipitation over Bulgaria. Theoretical Applied Climatology: 1-15.

[34] Özşahin, E., Duru, U., Eroğlu, İ. (2018): Land use and land cover changes (LULCC), a key to understand soil erosion intensities in the Maritsa Basin. - Water 10: 335-350.

[35] Panagos, P., Borrelli, P., Meusburger, K., Yu, B., Klik, A., Lim, K. J., Yang, J. E., Ni, J., Miao, C., Chattopadhyay, N. (2017): Global rainfall erosivity assessment based on hightemporal resolution rainfall records. - Scientific Reports 7: 4175.

[36] Panagos, P., Borrelli, P., Meusburger, K., Zanden, E. H. V. D., Poesen, J., Alewell, C. (2015): Modelling the effect of support practices (P-factor) on the reduction of soil erosion by water at European scale. - Environmental Science Policy 51: 23-34.

[37] Peng, C., Lin, Y. M., Chen, C. (2012): Destruction of vegetation due to geo-hazards and its environmental impacts in the Wenchuan earthquake areas. - Ecological Engineering 44: 61-69.

[38] Ran, L. I. (2015): Research on the ecological benefits of soil conservation of Yulin City based on InVEST model. - Arid Zone Research 32(5): 882-889.

[39] Rao, E., Xiao, Y., Ouyang, Z. (2013): Spatial characteristics of soil conservation service and its impact factors in Hainan Island. - Acta Ecologica Sinica 33: 746-755.

[40] Renard, K. G., Foster, G. R., Weesies, G. A., Mccool, D. K., Yoder, D. C. (1997): Predicting Soil Erosion by Water: A Guide to Conservation Planning with the Revised Universal Soil Loss Equation (RUSLE). - Agricultural Handbook. US Government Printing Office, Washington, DC.

[41] Rompaey, A. J. J. V., Govers, G., Puttemans, C. (2010): Modelling land use changes and their impact on soil erosion and sediment supply to rivers. - Earth Surface Processes Landforms 27: 481-494.

[42] Rulli, M. C., Offeddu, L., Santini, M. (2013): Modeling postfire water erosion mitigation strategies. - Hydrology and Earth System Sciences 17(6): 2323-2337.

[43] Sahin, S., Kurum, E. (2002): Erosion risk analysis by GIS in environmental impact assessments: a case study - Seyhan Köprü Dam construction. - Journal of Environmental Management 66: 239-247.

[44] Santillan, J., Makinano, M., Paringit, E. (2011): Integrated Landsat image analysis and hydrologic modeling to detect impacts of 25-year land-cover change on surface runoff in a Philippine watershed. - Remote Sensing 3: 1067-1087.

[45] Sharma, E., Bhuchar, S., Xing, M. A., Kothyari, B. P. (2007): Land use change and its impact on hydro-ecological linkages in Himalayan watersheds. - Tropical Ecology 48(2): 151-161.

[46] Stefano, C. D., Ferro, V., Burguet, M., Taguas, E. V. (2016): Testing the long term applicability of USLE-M equation at an olive orchard microcatchment in Spain. - Catena 147: 71-79.

[47] Tang, C., Zhu, J., Ding, J., Cui, X., Chen, L., Zhang, J. (2011): Catastrophic debris flows triggered by a 14 August 2010 rainfall at the epicenter of the Wenchuan earthquake. Landslides 8: 485-497.

[48] Teng, H., Liang, Z., Chen, S., Yong, L., Rossel, R. A. V., Chappell, A., Wu, Y., Zhou, S. (2018): Current and future assessments of soil erosion by water on the Tibetan Plateau based on RUSLE and CMIP5 climate models. - Science of the Total Environment 635: 673-686.

[49] Vittoz, P., Stewart, G. H., Duncan, R. P. (2001): Earthquake impacts in old-growth Nothofagus forests in New Zealand. - Journal of Vegetation Science 12: 417-426.

[50] Wang, F. X., Wang, Z. Y., Lee, J. H. W. (2007): Acceleration of vegetation succession on eroded land by reforestation in a subtropical zone. - Ecological Engineering 31: 232-241.

[51] Wang, L., Qian, J., Qi, W. Y., Li, S. S., Chen, J. L. (2018): Changes in soil erosion and sediment transport based on the RUSLE model in Zhifanggou watershed, China. - Proc. IAHS 377: 9-18. 
[52] Wang, W., Jiao, J. (1996): Quantitative evaluation on factors influencing soil erosion in China. - Bulletin of Soil Water Conservation 16(5): 1-20.

[53] Williams, J. R. (1975): Present and Prospective Technology for Predicting Sediment Yields and Sources: Proceedings of the Sediment-Yield Workshop. - U.S. Department of Agriculture, Agricultural Research Service, Washington, DC.

[54] Wischmeier, W. H., Smith, D. D. (1978): Predicting Rainfall Erosion Losses. A Guide to Conservation Planning. - Agric Handbook 537. USDA, Washington, DC.

[55] Xiao, W., Zhao, X., Zhang, Z., Ling, Y., Zuo, L., Wen, Q., Fang, L., Xu, J., Hu, S., Liu, B. (2016): Assessment of soil erosion change and its relationships with land use/cover change in China from the end of the 1980s to 2010. - Catena 137: 256-268.

[56] Yao, X. L., Bo-Jie, F. U., Yi-He, L., Sun, F. X., Guo, X. J. (2013): The soil moisture interpolation method based on GIS and statistical models in Loess Plateau region. Journal of Soil Water Conservation 27(6): 93-102.

[57] Yong, L. I. (2006): Sedimentary responses to late cenozoic thrusting and strike-slipping of Longmen Shan along eastern margin of Tibetan Plateau. - Acta Sedimentologica Sinica 24: 153-164.

[58] Zhai, W. F., Lin-Shu, X. U. (2011): Study on the soil erodibility K-value in the typical black region of Northeast China. - Chinese Journal of Soil Science 42(5): 1209-1213.

[59] Zhang, S., Fan, W., Li, Y., Yi, Y. (2017): The influence of changes in land use and landscape patterns on soil erosion in a watershed. - Science of the Total Environment 574: $34-45$.

[60] Zhang, Y., Liu, X., Li, Z., Zhu, Q. (2012): Surveying soil erosion condition in Loess Plateau using soil erosion model. - Transactions of the Chinese Society of Agricultural Engineering 28: 165-171.

[61] Zhao, G., Kondolf, G. M., Mu, X., Han, M., Zhong, H., Zan, R., Fei, W., Peng, G., Sun, W. (2017): Sediment yield reduction associated with land use changes and check dams in a catchment of the Loess Plateau, China. - Catena 148: 126-137.

[62] Zhujun, C., Lei, W., Ansheng, W., Jingbo, G., Yongli, L., Jianbin, Z. (2019): Land-use change from arable lands to orchards reduced soil erosion and increased nutrient loss in a small catchment. - Science of the Total Environment 648: 1097-1104. 